\title{
Purple Nutsedge Suppression with Soil-applied Paclobutrazol
}

\section{Osamu Kawabata and Joseph DeFrank Department of Horticulture, University of Hawaii, Honolulu, HI 96822}

Additional index words. Cyperus rotundus, weed control, growth regulator, container culture

Purple nutsedge (Cyperus rotundus L.) is difficult to control and one of the world's worst weeds (Holm et al., 1977). Cytokinins (Teo and Nishimoto, 1973) and 2-chloro-9hydroxy-9H-fluorene-9-carboxylate methylester (morphactin) (El-Masry and Rehm, 1977) enhanced nutsedge tuber sprouting, but we found no reports of suppression of rhizome growth or tuber production with growth regulators. In yellow nutsedge, soil-applied gibberellic acids altered rhizome orientation (Bendixen, 1970). Because $\beta-[(4-$ chlorophenyl)methyl] $-\alpha-(1,1$-dimethylethyl)-1H1,2,4-triazole-1-ethanol (paclobutrazol) interferes with gibberellin synthesis (Graebe, 1987), it may suppress underground growth of purple nutsedge. The objective of this study was to determine if paclobutrazol would suppress purple nutsedge propagule production while allowing leaf growth for absorption of foliar herbicide sprays.

Tubers and soil (Waialua, very-fine, kaolinitic, isohyperthermic,Typic Haplustoll) were collected at the Waimanalo Experiment Station, Waimanalo, Hawaii, on 1 Dec. 1989. The soil was fumigated with $4.5 \mathrm{~g}$ methyl bromide/ liter and sieved through a 5-mm mesh screen. On 5 Dec. 1989, 40 tubers weighing 0.6 to 0.8 $\mathrm{g}$ each were planted $2 \mathrm{~cm}$ deep in 1-liter black plastic containers.

In the drench treatment, $20 \mathrm{ml}$ aqueous solution of paclobutrazol (50\% wettable powder) at $0,0.5,2$, or $8 \mathrm{mg}$ a.i./liter soil was poured onto the soil followed by an additional $80 \mathrm{ml}$ water; in the incorporation treatment paclobutrazol was premixed with the soil. Tubers were planted and $100 \mathrm{ml}$ water was applied. The range of paclobutrazol concentrations was based on previous reports (Johnson, 1990; Stang and Weis, 1984). Each container received $0.55 \mathrm{~g}$ slow-release $18 \mathrm{~N}-2.6 \mathrm{P}-$ $9.9 \mathrm{~K}$ fertilizer and $20 \mathrm{mg}$ minor elements (Micromax, Grace Sierra, Milpitas, Calif.) and then was placed on outdoor benches and watered twice daily.

Received for publication 5 June 1992. Accepted for publication 27 Aug. 1992. Hawaii Inst. of Tropical Agriculture and Human Resources (HITAHR) Journal Series no. 3718. The use of trade names in this publication does not imply endorsement by the HITAHR of the products named nor approval to the exclusion of other products or vendors that also may be suitable. The cost of publishing this paper was defrayed in part by the payment of page charges. Under postal regulations, this paper therefore must be hereby marked advertisement solely to indicate this fact.
Plants were harvested 31 Jan. 1990, when nontreated plants reached anthesis. Data recorded were rhizome length (1-mm minimum), number of propagules produced (excluding planted tuber and primary basal bulb, 2-mmdiameter minimum), and length of the largest leaf. During the 57 days of growth, daily air maxima fluctuated between 21 and $31 \mathrm{C}$ and daily minima between 13 and $21 \mathrm{C}$.

Treatment design was factorial, two application methods $\times$ four paclobutrazol levels, with five replications. The experimental design was completely randomized, and the experimental unit was a rhizome system developed from a parent tuber. Plant responses to the treatments were regressed with modified power functions (Spain, 1982) using SAS GLM and NONLIN procedures (SAS Inst., 1990).

Plants in control pots produced $1177 \pm 182$ $\mathrm{mm}$ (mean $\pm 95 \%$ confidence intervals) total rhizome length compared with $343 \pm 163 \mathrm{~mm}$ for those with paclobutrazol at $0.5 \mathrm{mg}$ a.i. Purple nutsedge rhizomes were almost eliminated at 2 and $8 \mathrm{mg}$ a.i. Regressing the concave response with a modified power function (Fig. 1A) was satisfactory, as the model estimated means (1168 and $324 \mathrm{~mm}$ for 0 and $0.5 \mathrm{mg}$ a.i., respectively) within $95 \%$ confidence intervals. Because no significant difference was found among two application methods, one prediction equation was developed with the combined data.

The number of propagules produced in response to paclobutrazol concentration (Fig. 1B) followed the same trend as total rhizome length. Tuber production was suppressed by paclobutrazol at $0.5 \mathrm{mg}$ a.i. and completely inhibited at 2 and $8 \mathrm{mg}$ a.i.

Leaf length also showed a concave response to paclobutrazol treatments (Fig. 1C), but leaf elongation was not completely inhibited at the highest paclobutrazol level. While leaves from nontreated soil were $201 \mathrm{~mm}$ long, paclobutrazol applications at 2 and $8 \mathrm{mg}$ a.i. limited leaf length to 96 and $64 \mathrm{~mm}$, respectively.

In summary, purple nutsedge growth was suppressed by paclobutrazol soil drench or incorporation. Rhizome growth and propagule production were eliminated by paclobutrazol at 2 and $8 \mathrm{mg}$ a.i./liter soil, while leaf length was limited to $48 \%$ and $32 \%$, respectively, of nontreated plants.

\section{Literature Cited}

Bendixen, L.E. 1970. Altering growth form to precondition yellow nutsedge for control. Weed Sci. 18;599-603.

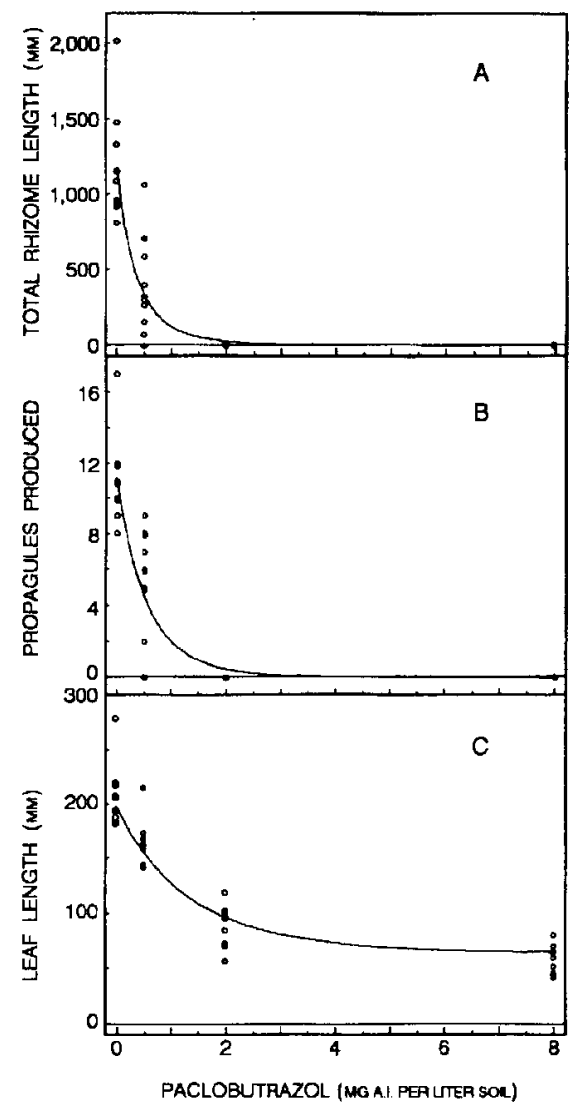

Fig. 1. Purple nutsedge total rhizome length (A), number of tubers produced (B), and leaf length (C) 57 days following soil applications of paclobutrazol at $0,0.5,2$, or $8 \mathrm{mg}$ a.i./liter. The responses $(\bigcirc)$ were regressed with modified power functions (-): total rhizome length (in millimeters $)=(0.192+0.134 \times \text { paclobutrazol })^{-4.28}$, number of tubers produced $=(0.760+0.163 \times$ paclobutrarol $)^{-8.77}$, and leaf length (in millimeters $)=62.47+1.03 \times(0.520+0.054 \times$ paclobutrazol) $)^{-7.49}$, where paclobutrazol (in milligrams) is a.i./liter soil.

El-Masry, R. and S. Rehm. 1977. The effects of growth regulators and herbicides on purple nutsedge (Cyperus rotundus L.). IV. Effects of glyphosate and morphactin on the viability of tubers. Z. Acker- und Pflanzenbau 144:259267.

Graebe, J.E. 1987. Gibberellin biosynthesis and control. Annu. Rev. Plant Physiol. 38:419-465.

Holm, L.G., D.L. Plucknett, J.V. Pancho, and J.P Herberger. 1977. The world's worst weeds. Univ. Press of Hawaii, Honolulu. p. 8-24.

Johnson, B.J. 1990. 'Tifway' bermudagrass responses to plant growth regulator application dates. HortScience 25:436-438.

SAS Institute. 1990. SAS/STAT user's guide, version 6, 4th ed. SAS Institute, Gary, N.C.

Spain, J.D. 1982. BASIC microcomputer models in biology. Addison-Wesley, Reading, Mass.

Stang, E.J. and G.G. Weis. 1984. Influence of paclobutrazol plant growth regulator on strawberry plant growth, fruiting, and runner suppression. HortScience 19:643-645.

Teo, C.K.H. and R.K. Nishimoto. 1973. Cytokininenhanced sprouting of purple nutsedge as a basis forcontrol. Weed Res. 13:118-121. 